Riva Sobrado de Freitas ${ }^{1}$

Vinícius Almada Mozetic 2

DANIELA ZILIO

University of the West of Santa Catarina

\title{
ABORTION: A LOOK INTO THE PERSPECTIVE OF PRIVACY RIGHTS AND DECISION-MAKING AUTONOMY
}

Keywords: Abortion, Privacy, Decision, Autonomy, Self-determination, Right to own body

1 Post-doctoral degree in Law from the University of Coimbra; Doctor and master in Law by PUC / SP; Coordinator, researcher and professor of the Post-Graduate Program in Law of the University of the West of Santa Catarina (UNOESC); Retired assistant professor at the State University of São Paulo Júlio de Mesquita Filho - UNESP. University of the West of Santa Catarina (UNOESC). Rua Nereu Ramos, 3777-D, Bairro Seminário Chapecó / SC - CEP: 89813-000. E-mail: rivafreit@ig.com.br

2 Doctor in Law from the University of Vale dos Sinos River - UNISINOS; Master in Law from the University of Santa Cruz do Sul - UNISC - Social Rights and Public Policies; Professor and Researcher of the Post-Graduation Program in Law of the University of the West of Santa Catarina - UNOESC and lawyer. University of the West of Santa Catarina (UNOESC). Rua Nereu Ramos, 3777-D, Bairro Seminário - Chapecó / SC - CEP: 89813-000. E-mail: vinicius.mozetic@unoesc.edu.br

3 Master's degree in Law from the University of Western Santa Catarina (UNOESC); Specialist in Civil Law and Civil Procedural Law from the University of the West of Santa Catarina (UNOESC); Graduated in Law from the University of Western Santa Catarina (UNOESC). University of the West of Santa Catarina (UNOESC). Rua Nereu Ramos, 3777-D, Seminary Neighborhood - Chapecó / SC - CEP: 89813-000 E-mail: danielazilio@yahoo. com.br 


\section{INTRODUCTION}

T he main focus of the study is the controversy over abortion, an extremely important and conflicting subject, from a juridical, moral, ethical and philosophical point of view.

However, there is no scope to bring up the recurrent discussion on the right to life of the unborn versus the right to freedom of the pregnant woman. What is needed, therefore, is a fundamental investigation on what the defense arguments are based on the practice of abortion. These arguments are primarily related to the right to privacy and the right to self-determination of the body which in itself is purposely pleonastic in terms of autonomy in decision-making.

The study is justified, and, the theme on which it is based is extremely contemporary and timeless; presenting the controversy in the human mind since time immemorial. In addition, the problem involves moral, ethical, philosophical and legal guidelines, as well as religious, medical, sociocultural and political aspects. Therefore, the debate on the subject is always necessary and elucidates important issues, especially when starting from a specific perspective of analysis, as is the case of the study, which seeks to understand the problem of abortion from the viewpoint of right to privacy and right to self-determination of one's own body, based on decision-making autonomy.

The problem of the study is based on the questioning made from the proabortion arguments, such as their bases and their importance.

The objective generally, is to study the ideals that justify abortion. Specifically, to visualize the hypotheses in which it is allowed in the legal order of the country, to establish the intrinsic and sacred ideals related to the development in human life, to analyze the right to privacy and the decisionmaking autonomy when confronting the subject, And finally, to provide an overview of the difficulty of defining what is, in fact, right, or wrong, and, consequently, the difficulty of positioning the issues related to the theme.

To do so, the study will be systematized so that, first, a brief evaluation will be made generally on the subject (abortion), then the analysis will delve into Brazilian law and the conjectures in which abortion is allowed. Fur- 
:::: R. S. de Freitas, V. A. Mozetic, D. Zilio, Abortion...

thermore, it will analyze the values of decision-making autonomy and the right to privacy, and, finally, the concept of a "good life" from the Habermasian point of view, as well as the difficulty of positioning on the subject from the social point of view.

It should be pointed out that, as mentioned elsewhere, it is not the purpose of this study to present the conflict between the right to life and the right to autonomy, nor is it favorable to choose one of these fundamental rights over another, but is the argument used by a great majority of women who fervently fight for the right to abort, a right based on decision-making autonomy, the right to privacy and the right to own body as part of human individuality. What is intended, then, is to reflect on the importance of the right to privacy and the right to self-determination on one's own body in terms of decision-making autonomy, and not to contrast those rights with the right to life, or to position oneself in relation to abortion contraceptive.

Regarding the methodological aspect, the research is based on technical, rational and systematic procedures, with the intention of scientific foundation, as well as providing logical base for research. Finally, it is a research of exploratory-explanatory, qualitative bibliographical collection, in which the deductive method is used, and in which one has the intention of starting from hypotheses to explore and to describe the subject of discourse, revealing the possible solutions to the argument presented, without however, exhausting the theme.

\section{AbORTION: INITIAL SIGNIFICANT CONSIDERATIONS}

Matters strictly involving personal decisions almost always generate contradictions and conflicting opinions, especially from a moral point of view. Resolutions involving women's rights as part of the human population has always been stigmatized and is historically viewed as more vulnerable, therefore generating even more polemics, despite the fact that what is needed is the feasibility of some of the rights. Abortion may present the greatest, or one of the greatest controversies as it pertains to such decisions. 
However, abortion or the process of abortion can be characterized as the interruption of the natural process of gestation, in which, for Reinaldo Pereira e Silva, the prenatal death of intrauterine human life occurs ${ }^{4}$.

According to Maria Helena Diniz, the term "abortion" comes from the Latin word abortus, coming from aboriri, which means to die, to perish, and has been used to indicate the interruption of the gestation process, before natural time. Although this might be spontaneous or not, it however leads to the expulsion of the fruit of conception ${ }^{5}$.

According to Diniz, in the northern part of Brazil, the opinion of obstetricians there is that there is a distinction between abortion and premature delivery, which is the interruption of pregnancy during the first six months of intrauterine life, taking into account the possible immaturity of the fetus $^{6}$. On the other hand, preterm birth occurs after the sixth month of gestation, if the product of conception persists alive.

There are several ways of classifying abortion. In relation to the cause of it, it can be divided into spontaneous and instigated. Well, as far as natural or spontaneous abortion is concerned, there is nothing conflictive, at least in the moral, ethical, and primarily juridical spheres. On the other hand, when discussing the possibility of termination of pregnancy by the woman's desire not to undergo the pregnancy process, the discussion is large and indeed conflictive.

Moreover, in relation to the legal scope, there is some divergence regarding the conceptualization of abortion. Some understand it as the premature, violent and intentionally forced expulsion of the fetus, regardless of viability, age or even regular training, not considering the hypothesis that there is abortion without the product of conception being expelled, which may be absorbed by the fetus. In this case, the body of a pregnant woman undergoes a process of mummification. Others, however, relate abortion to feticide because they cover the destruction of gestation only at the moment when the product of conception reaches the fetal period. Finally, some others evaluate abortion as the interruption of pregnancy, whether or not it is

${ }^{4}$ R. P. Silva, Introdução ao biodireito: investigações político-jurídicas sobre o estatuto da concepção humana, São Paulo: LTr, 2002, p. 255.

${ }^{5}$ M. H. Diniz, O Estado Atual do Biodireito, Saraiva, São Paulo 2001, p. 31.

${ }^{6}$ Ibidem. 
:::: R. S. de Freitas, V. A. Mozetic, D. Zilio, Abortion...

ejected from conception, before maturity, covering the period corresponding to the conception until the beginning of delivery, according to Diniz ${ }^{7}$. As a rule, the viability of the fetus is not taken into account for the conceptualization of abortion. In principle, the chronological criterion is inapplicable.

Opinions, regardless of the sphere of argument are extremely divergent, ranging from extremely liberal and pro-abortion opinions, regardless of the situation, to those more conservative, where, on the other hand, abortion is not justified in any situation. Among these two conceptions, there are still several others, according to Ronald Dworkin ${ }^{8}$.

For the author, people's opinions do not have two single variants, one conservative and one liberal. Conservatives and liberals alike have degrees of opinion ranging from the most extreme to the moderate, and there are also differences of opinion that cannot be found in the conservative-liberal spectrum. An example of this, for Dworkin, is the view that a late abortion is worse than a preterm abortion, since such a view cannot be clearly identified as more liberal, or more conservative ${ }^{9}$.

Moreover, on the discussion of opposing and favorable arguments to the practice of abortion, José Roque Junges reiterates that in a pluralistic and democratic society, the way to influence the search for solutions to certain problems is precisely through dialogue and participation in convincing arguments $^{10}$.

According to the author, many times the groups organized to fight against abortion are made up of members who do not care about changing the social structures of society that cause abortion. Thus, the defense of human life from fertilization can be hypocritical if it does not worry about the social stigma that the future child will receive, that is, when it is not aborted in the womb. The social stigma typifies a condition of life with lack of social dignity, and the question of abortion permeates this broader perspective. Still, Junges argues that abortion-friendly groups also do not struggle for

\footnotetext{
7 Ibidem.

${ }^{8}$ R. Dworkin, Domínio da Vida: aborto, eutanásia e liberdades individuais, trad. J. L. Camargo, Martins Fontes, São Paulo 2003, p. 41.

${ }^{9}$ Iidem, p. 42.

${ }^{10}$ J. R. Junges, Bioética: perspectivas e desafios, Unisinos, São Leopoldo 1999, p. 131.
} 
change, proposing that to be the solution, when one does not have the courage to go deeper into the issue ${ }^{11}$.

However, Sueli Gandolfi Dallari explains that abortion is a typical case where the positions on the ethical foundation are irreconcilable. According to the author, in addition, the positions frequently placed do not define all cultures in all epochs of the history of the humanity. Nowadays, with the predominance of Christian culture, there is a strong position that life should be protected and protected by states, usually from conception - which in no way makes opposing ideals less strong ${ }^{12}$.

So, the struggle for female empowerment ${ }^{13}$ and the consequent decriminalization of abortion continues with increasingly significant proportions. In addition, September 28 was set aside as the Day of Fight for the Decriminalization of Abortion in Latin America and the Caribbean, or Latin American and Caribbean Day for the Legalization of Abortion. The definition of such date occurred at the 5th Latin American and Caribbean Feminist Meeting held in Argentina in 1990, according to information from the Brazilian Institute of Criminal Sciences ${ }^{14}$.

The struggle for the decriminalization of abortion is grounded on the fact that this would protect the life and liberty of women, and that punishing the practice would not prevent new abortions from happening, but would impel their realization clandestinely and insecurely, so that the right to abortion would be a public health issue. It should be noted that Latin American and Caribbean women seek the realization of the right to interrupt gestation, if they so wish, through the strong argument that the criminalization of abortion causes women to seek this type of service clandestinely, which has led many of them to suffer very serious consequences, death being the worst of them. In Latin American and Caribbean countries, with few excep-

11 Ibidem, p. 132.

12 S. G. Dallari, Aborto - Um Problema Ético da Saúde Pública, "Revista Bioética, Brasília" 2 (1994), No. 1, p. 1.

13 On the issues of gender, feminism, and the struggle for women's rights, Judith Butler, an American philosopher and author of truly critical works on the subject, stands out.

14 Dia Latino-Americano pela Legalização do Aborto na América Latina e Caribe 28 de Setembro. São Paulo: IBCCRIM, 2010. p. 1. 
:::: R. S. de Freitas, V. A. Mozetic, D. Zilio, Abortion...

tions ${ }^{15}$ abortion is not legalized (or is only in specific situations). The legislation of Brazil is still quite conservative in relation to the subject that will be discussed below.

Therefore, considering the points of view and analyzing their arguments in depth, it is essential to bring to the discussion concrete ideals, unnecessary prejudices and pre-judgments that are absolutely unnecessary.

Nonetheless, it is important to note that, despite the extremely controversial subject, there are currently hypotheses where abortion is admitted and accepted by the Brazilian legal system, although controversial.

\section{The Legality OF the INTERRUPtion OF PREgNANCY IN NATIONAL LAW: ABORTION IN CASE OF RISK OF DEATH FOR THE PREGNANT WOMAN AND IN CASE OF RAPE AND THERAPEUTIC ADVANCEMENT OF CHILDBIRTH IN FETAL ANENCEPHALY}

The issue of allowing or legalizing abortion was, and is, an extremely controversial issue. The discussion permeates medical ethics and enters specifically in the legal sphere, before the very discussion about the autonomy of the pregnant woman as part of her right to privacy.

On the subject, Dworkin argues that it is as a result of the latency of the population that the discussion is based on a moral and metaphysical question - whether even a newly fertilized embryo is already a human creature with rights and interests ${ }^{16}$. In fact, there is the involvement of an entire ethical sphere in the discussion, as well as the biological aspect of when life begins.

Uadi Lammêgo Bulos argues that the constitutional text protects all life forms, that is, both the external (intrauterine) life expectancy and its effective (extrauterine) consummation, in two aspects: birthright and right to live or survive ${ }^{17}$. For this reason, in Brazilian moral law, abortion, in general, is considered a crime.

\footnotetext{
15 Among the countries that have legalized abortion in Latin America are Uruguay, which recently decriminalized the practice in the first 12 (twelve) weeks of a Latin American decision in 2012. Gestation, under some conditions.

${ }^{16}$ R. Dworkin, op.cit., p. 41.

17 U. L. Bulos, Constituição federal anotada, Saraiva, São Paulo 2008 [8th. ed.], p. 113.
} 
In spite of this, there are currently hypotheses in which the practice is legalized, with the exclusion of crime, as in the case of the possibility of death of the pregnant woman, and in the case of rape. After the recent decision of the Supreme Court, in cases of fetal gestation with anencephaly, there is the possibility of therapeutic anticipation of delivery.

Regarding abortion in the case of the possibility of death of the pregnant woman, the Penal Code recommends in its Art. 128, item I, that abortion practiced by a physician is not punished if there is no other way to save the life of the pregnant woman. Also, in case of rape, abortion is admitted according to Art. 128, item II, of the same Penal Code, which establishes that if the pregnancy results from rape and abortion is preceded by consent of the pregnant woman or, when incapable, of her legal representative, there is no punishment.

Also, as discussed elsewhere, therapeutic anticipation of delivery is currently permitted when the developing fetus has anencephaly. This position is based on the decision of the Federal Supreme Court, in regard to the Arrangement of Non-compliance with Basic Precept (ADPF 54, judged in April 2012). In this judgment typified in Art. 124, 126 and 128, items I and II, of the Criminal Code, the Court acknowledged the right to therapeutic anticipation of labor in the case of gestation of anencephalic fetuses, since it was decided that the interpretation according to which the interruption of gestation of the anencephalic fetus is conducted.

Although the case cannot be termed abortion, because the anencephalic fetus is missing from the expectation of extrauterine life, it is perceived that it denotes the incessant search for the protection of the most basic rights of women who experience this delicate situation.

According to the Minister Marco Aurélio Mendes de Farias Mello, the case's rapporteur, the hypothesis is clearly a therapeutic anticipation of childbirth, to the detriment of the term "abortion", since in view of the unviable survival of the fetus in the postpartum period, one cannot speak in greater protection of this, than to the dignity and freedom of choice of the mother, or of the parents. It should be noted that this asserted freedom corresponds precisely with the decision-making autonomy of the pregnant woman, even more so in a case as crucial as this, in which, in fact, the suffer- 
:::: R. S. de Freitas, V. A. Mozetic, D. Zilio, Abortion...

ing in carrying forward a pregnancy in which is considered the non-viability of life of the newborn can hurt the rights of the woman herself.

Even the judgment of the Arrangement of Precedence of Fundamental Precept explained that women's right to sexual and reproductive freedom, their right to health, both physically and psychologically, and their right to self-determination were recognized.

The rapporteur clarified that the right to life was not an absolute right, and even mentioned in his vote that the rights of women should not be annihilated for the protection of the rights of the fetus, especially in this case where it is known that there is the impossibility of extrauterine life. That is, it would impose too great a sacrifice on the woman to cause her to carry on a gestation, where the result would be the death of the fetus. Such maintenance would run counter to basic rights, as already mentioned, harming women's personal dignity, as well as their right to privacy, self-determination, their sexual and reproductive rights, and even their right to health.

At the same time, maintaining gestation would restrict the woman's right to psychophysical integrity, imposing on her an unreasonable restriction of her right to self-determination, causing her to live in a kind of imprisonment deprived of her own body.

Note that it has been decided that the safety of a fetus, which will not survive outside the womb, and even if it does, will be for very little time ${ }^{18}$ cannot and should not be preserved at any cost, to the detriment of the most basic rights of women.

Thus, finally, it is accepted that abortion as a gender issue is still analyzed as a crime in the legal order of the country. However, in some specific situations, there is exclusion of crime, denoting that in the confrontation of some rights, especially of the pregnant woman, to the detriment of the pure and unique protection of the life of the fetus - without going into exactly the theories of the beginning of human life and personality - the rights of the latter may prevail, or, at least, in the weighing of interests, be taken into ac-

${ }^{18}$ As regards the action in question, several authorities in the subject were heard in a public hearing in order to better understand the anomaly, and, therefore, to discern on the subject with greater base and exempt manner. According to experts, anencephaly is completely incompatible with extrauterine life. In fact, cases where extra-uterine survival of the anencephalic baby was believed to have been clarified by experts. Diagnostic errors were undeniably the trigger for such beliefs. 
count. The same occurs with regard to the therapeutic anticipation of delivery, in the case of pregnancy of an anencephalic fetus.

However, to achieve the prerogative of abortion, even in specific situations, some obstacles must be overcome, obstacles that have been instilled in the human mind since the earliest times. This is the case of the belief in the inviolability of intrauterine human life, because of its sacredness, as can be seen below.

\section{SACRALITY AND the INTRINSIC VALUe ATtRIBUted} TO INTRAUTERINE HUMAN LIFE AND THE DISCUSSION ABOUT ABORTION

Human life is, without a shadow of doubt, the most heavily protected value in legal terms, and likewise in relation to moral issues. Because of this fact, when talking about abortion, the controversy is always great.

There is, however, one who strongly argues that the question of the moral prohibition of abortion does not necessarily lie in the question of whether or not the fetus is human life, in the sense of being already a person, but in the protection of intrinsic value and of this life itself.

From his turn, Dworkin believes that people consider it to be intrinsically regrettable that human life initiated has a premature end. Concerning the idea of sacredness, the author asserts that in principle, something is intrinsically important if its value is independent of what people appreciate or need. Then the life of the fetus would be of intrinsic value whether or not it had instrumental or personal value ${ }^{19}$.

When he speaks of the sanctity of human life, Dworkin reports that this is partly seen because it is believed that man is made in the image and likeness of $\operatorname{God}^{20}$. Yet the idea that each individual human life is inviolable is rooted in two bases of sacredness, namely, natural creation and human creation.

Similarly, Junges explains that, in the sacral conception, life is owned by God, and the human being is its mere administrator, and it is conceived as something untouchable ${ }^{21}$.

\footnotetext{
${ }^{19}$ R. Dworkin, op.cit., p. 96.

20 Ibidem, p. 96.

${ }^{21}$ J. R. Junges, op.cit., p. 113.
} 
:::: R. S. de Freitas, V. A. Mozetic, D. Zilio, Abortion...

Edison Tetsuzo Namba, emphasized, as well that life granted by divinity, or even by the intrinsic finality of nature, would have a sacred status and, in this way, could not be willing, even if it were the expressed will of its holder ${ }^{22}$.

In addition, Dworkin argues that even conservatives consider that abortion is possible for the sake of the mother's life, and that there is a controversy, since these same people almost always consider it impossible for a person to kill someone to save the life of another ${ }^{23}$. Would that exactly not be likened to the role of the doctor? For the author, the more exceptions allowed, the more clearly the conservative opposition to abortion does not assume that the fetus is a person endowed with the right to life.

On the other hand, liberal conceptions do not stem simply from the denial that the fetus has the right to life as a person.

A paradigmatic liberal position rejects the view that abortion is morally problematic, but it is morally justified for a number of important reasons. Also, a woman's concern for her own interests is taken as justification for abortion when the consequences of the child's gestation and birth are serious. In addition, the other component of the liberal conception is political opinion, in the sense that the State should not intervene, nor to prevent abortions that are not morally permissible.

Dworkin mentions that in the Western world, even with a separate church and state, the discussion of abortion almost always has the character of conflict between religious sects. Religious practitioners tend to have a strongly conservative view of the subject. Both the ideas of the more conservative religious and those of the more liberal, who support abortions and exceptional conditions, are not based on the fact that the fetus is a person, but the fact that any human life has intrinsic and sacred value ${ }^{24}$.

For many centuries, the author claims, it was believed that the church's traditional conception that abortion might be condemned for insulting the sanctity of life, even if the fetus had no soul, would be able to sustain opposition to premature abortion. There is also a debate between historians and philosophers of religion to know what would have triggered the change of

22 E. T. Namba, Manual de bioética e biodireito, Atlas, São Paulo 2009, p. 53.

${ }^{23}$ R. Dworkin, op.cit., p. 43.

24 Ibidem, p. 48. 
thought that the fetus would be endowed with soul some time after conception for the thought of immediate animation. Dworkin adds that practicing Catholics, if they truly believed that the fetus is a person with a right to life from conception, could not accept the exceptions they accept for the most part $^{25}$.

See, quoting a research by sociologist Carol Gilligan, a professor at Harvard University, the author argues that, even with uncertainties, no woman who intended to abort cast doubt on the question of whether the fetus was a person or not. They also questioned their responsibilities in the sense that it was wrong to have a child they could not properly care for.

He describes the author as a description of what most people view as the moral defect of abortion. To make an abortion is to belittle the inviolability/sanctity of human life, configuring a moral defect, unless the intrinsic worth of other lives were neglected in the decision against practice ${ }^{26}$.

Finally, Dworkin cites a decision of the European Court of Human Rights, which led to the assumption that the fetus is not a person with its own rights and interests, and that the laws that regulate and prohibit abortion are justified Only on the basis of the fact that its realization is considered as a risk to the value inherent in human life ${ }^{27}$.

The case, in summary, concerns the trial that decided to ban the disclosure of abortion clinics in Ireland through counseling services on abortion issues, because such disclosure would hurt freedom of expression and information. There was a proportionality test between abortions that could be avoided and it was decided that the number would be too small to violate the rights to expression and information. For the author, it remains clear that the proportionality test presupposes that laws prohibiting abortion are not intended to prohibit a murder, but to allow one to perceive the inherent value of life ${ }^{28}$.

It should be noted that, under this argument, it is clear that rejection of abortion is not a matter of the fetus being a person endowed with rights and prerogatives from conception, but by the fact that initiated human life is sa-

\footnotetext{
25 Ibidem, p. 65.

${ }^{26}$ Ibidem, p. 83.

27 Ibidem, pp. 92-93.

${ }^{28}$ Ibidem.
} 
:::: R. S. de Freitas, V. A. Mozetic, D. Zilio, Abortion...

cred, and has intrinsic value, and cannot be violated under penalty of violating the sacred.

Thus, as explained above, the still sacralized perception of human life initiated is an argument for those who condemn the practice of abortion in any and all situations. Despite this, the right to privacy, and the decisionmaking autonomy of the pregnant woman, serve as a scope for her defense, as analyzed below.

\section{The RIGHT to PRIVACY AND DECISIONAL AUTONOMY AS PRO-ABORTION ARGUMENTS}

The right to privacy is a right of the personality, insofar as the personality rights seek to regulate the protection of the proper attributes to the individualization of a person, seeking the protection of intimate aspects of the individual, or aspects originated from their interaction or projection in society. The protection of the personal psychic sphere, thus, would be contemplated in the roll of these rights. Likewise, the protection of the attributes of the physical body, such as the right to one's own body or to separate parts of it, is also included in the proper rights of the personality, as explored by Carlos Alberto Bittar ${ }^{29}$.

In this way, it is often difficult to defend abortion by defending the recognition of women's identity, in the sense that there is a possibility that the abortion will preserve the pregnant woman's right to privacy and consequent decision-making autonomy rights inherent in the personal dignity of individuals, as stated.

This decision-making autonomy designates the individual as the center of his process, determining a sphere of self-determination in which she (in this case, woman) must exercise her concrete identity, making her own choices, even without having to justify herself, According to Jean L. Cohen ${ }^{30}$. In this way, according to Hannah Arendt, rights of this nature attribute to

29 C. A. Bittar, Os direitos da personalidade, Forense Universitária, Rio de Janeiro 1989, p. 69.

30 J. L. Cohen, Repensando a privacidade: autonomia, identidade e a controvérsia sobre o aborto, "Revista Brasileira de Ciência Política" 7 (2012), p. 185. 
the individual a "legal persona", which serves as a "shield of protection" for his personal identity ${ }^{31}$.

According to Paulo Otero, personal identity aims to guarantee what identifies the person as a singular and irreducible individual, possessing an absolute dimension, which makes each being unique and expresses the individuality of the physical and psychic personality and also a relative dimension, so that each human being, besides its singularity, has the identity defined, in parallel, by the "history" in which its existence is inserted ${ }^{32}$.

In the meantime, Cohen reports that women have the right to be treated as individuals, and not subject to any kind of restriction in view of the sex to which they belong, nor can they be placed in inferior positions, despite the juridical order of the country ${ }^{33}$. Only after the advent of the Federal Constitution of 1988, the woman was treated as a "head of the family", according to Maria Garcia ${ }^{34}$.

According to Cohen, both the protection of the voice in the public sphere and the protection of privacy in the intimate sphere are crucial in avoiding exclusion or leveling or even homogenization in a democratization project ${ }^{35}$.

Thus, the privacy in question is one that assures individuals of their decision-making autonomy as it relates to personal concerns.

According to Cohen, the principle that individual rights of privacy, which protect decision-making autonomy, is compatible with the recognition of the inter-subjective character belonging to the processes of formation of personal identity, and awareness of historical and contextual sources of values ${ }^{36}$.

In the same vein, personal privacy rights ensure domains of decisionmaking autonomy for all individuals, not generating a voluntary conception of the individual in any way. Thus, when the issue of autonomy appears in court decisions, it is not necessary to impose on them a voluntarist ideal of

31 H. Arendt, Origens do Totalitarismo, trad. R. Raposo, Companhia das Letras, São Paulo 1989, p. 126.

32 P. Otero, Personalidade e identidade pessoal e genética do ser humano : um perfil constitucional da bioética, Almedina, Coimbra 1999, pp. 63-64.

33 J. L. Cohen, op.cit., p. 165.

${ }^{34}$ M. Garcia, $O$ aborto e a condição feminina: nem le galização, nem criminalização, educação e apoio social - o Estatuto da Mulhe, [in:] M. Garcia, J. C. Gamba, Z. C. Montal (eds.), Biodireito constitucional: questões atuai, Elsevier, Rio de Janeiro 2010, p. 423.

${ }^{35}$ J. L. Cohen, op.cit., p. 169.

${ }^{36}$ Ibidem, p. 183. 
:::: R. S. de Freitas, V. A. Mozetic, D. Zilio, Abortion...

person. The attribution of decision autonomy to an individual simply militates against state paternalism.

Yet, the identity of the individual is not formed solely by group values. For Cohen, in different societies the rights to privacy play important roles in protecting individuals' capacities for training, maintenance, and presentation to others of a coherent, authentic and distinct self-concept ${ }^{37}$.

Thus, the new rights of privacy also protect identity in the face of leveling in the name of a vague idea of community or the conception of the majority about the common good. They protect individual differences in the face of the "norm" adopted by the society or group to which the individual belongs. In short, not only the right to be left alone, but the right of self-determination - the decision-making autonomy - Is protected by the right to privacy.

In addition, to enjoy a right to privacy that guarantees decision-making autonomy means not being forced to show the reasons why ethical choices are made, or even to submit to reasons or judgments of the group.

Regarding abortion, Cohen points out that all people are embodied individuals, that is, people are their bodies, the person's body is not extrinsic to what he is, and therefore, it is part of his personal dignity. Identities and individualities are intrinsically implicated with bodies and what is made of them, since the body is the mode of being of the person in the world ${ }^{38}$. Thus, in the question of abortion, what seems to be on the agenda is the identity and individuality of the woman, something intimate and worthy of protection. Hence, women who advocate abortion refer so much to the issue of having a right to one's own body.

At this very point, Riva Sobrado de Freitas and Narciso Leonardo Xavier Baez emphasized the importance of the term embodiment, which is significant in the sense of the body itself as the substratum of personal identity. As with the other dimensions of privacy, the integrity of the body is essential for the understanding of decision-making autonomy, and consequently, for the formation of one's own identity ${ }^{39}$.

37 Ibidem, p. 188.

38 Ibidem.

39 R. S. Freitas, N. L. X. Baez, Privacidade e o direito de morrer com dignidade, "Revista de Ciências Jurídicas Pensar" 19 (2014), No. 1, p. 251. 
In this way, imposing a woman to bear an unwanted gestation, in this perspective, would impose on her an identity, the identity of a pregnant woman and a mother, while bodily integrity, physically and emotionally, is at risk in the laws that criminalize the abortion, as well as the inviolability of the personality. The experience of pregnancy is a change in the personification of the woman and, consequently, in her identity and feeling of individuality, which pervade much the question of the corporal change.

In this case, bodily integrity is imperative for the identity of the individual, and deserves to be protected as such by the rights to privacy, only to be disregarded by an even greater state interest. However, there seems to be something more serious that involves the psychological integrity of the woman, since to impose on her the continuation of an unwanted gestation would be extremely invasive, causing several of her most elementary rights to be mitigated.

Cohen relates that questions concerning procreation are fundamental, since they involve the identity of the woman, her processes of self-assertion, and her own understanding of herself ${ }^{40}$. The question of the inviolability of the personality by the control of the body itself is indispensable to any notion of freedom. To consider the right to abortion as a right to privacy is to recognize the difference between women, letting each one define this difference.

Moreover, the best argument for the application of the constitutional right to privacy to abortion points to the physical and psychological costs of unwanted pregnancies, according to Dworkin ${ }^{41}$.

The author proclaims that feminists do not claim that the fetus is a person with moral rights of his own, but they report that he is a creature of moral importance. They emphasize the responsibility of the pregnant woman to make a decision that only she, and nobody better than she, can take.

On abortion and the right to privacy, it is very important to highlight the Roe versus Wade case ${ }^{42}$, American precedent of 1973, which recognized the right to abortion based on the right of privacy of the woman as an in-

40 J. L. Cohen, op.cit., p. 198.

41 R. Dworkin, op.cit., pp. 143-144.

${ }^{42}$ In relation to international cases on the subject, which has a repercussion beyond the national legal order, it is also worth examining the case 2141, known worldwide as the Baby Boy case, appreciated by the Inter-American Commission on Human Rights (IACHR), which resulted in Resolution 23/81 of March 6, 1981. 
:::: R. S. de Freitas, V. A. Mozetic, D. Zilio, Abortion...

dividual, considering that the pregnant woman and only her as an individual can make the decision to carry a pregnancy forward, or not, according to Dworkin ${ }^{43}$. It should be noted that in the case in question it was decided that the pregnant woman has the specific constitutional right to privacy in issues related to procreation, including abortion, provided she and her doctor choose to perform it.

According to Silva, with the ruling of the case in question, the US Supreme Court recognized the right to abortion based on the 14th Right of Privacy, so that in the first trimester of gestation, there is freedom for abortion without any state intervention, in the second trimester of gestation, this freedom may be limited by state regulations, and finally, in the third trimester of gestation, the state can veto the freedom to abortion. Thus, the Supreme Court assured the federal states of the possibility of establishing restrictions on abortion, in a progressive relation to the gestation period, justifying the protection of the fetus from the possibility of autonomous existence ${ }^{44}$.

In this way, finally, by analyzing the question in the light of women's right to self-determination, it can be said that it is up to them to look at themselves, to reflect on their own conceptions and to decide, based on their right to privacy, willingness to continue, or not, with gestation.

It should be noted, however, that at no time do these arguments seek to defend abortion as a contraceptive method, but rather seek to place under consideration the importance of bodily and psychic integrity, for the integrity of the personality as a whole. There is serious concern to ensure that women are not confined solely to their womb.

\section{The CONCEPt of "GOOd LIFE" Weighted in habermas: ABORTION AND THE DIFFICULTY OF POSITIONING UNDER THE SOCIAL POINT OF VIEW}

Apart from the right to self-determination of one's own body and the right to privacy, all individuals have, and deserve to have respect over their right to personal identity as a right inherent in the human personality. As already

43 R. Dworkin, op.cit., p. 141.

${ }^{44}$ R. P. Silva, op.cit., pp. 256-257. 
pointed out, the imposition of a gestation would be the imposition of a new identity on the woman, against her will, which could have devastating consequences.

Jürgen Habermas, in his brilliant scholarly work The Future of Human Nature, constantly mentions the right to personal identity when he relates his concern for each person's right to self-understanding ${ }^{45}$.

In the work in question, the Habermasian thought enters into extremely controversial questions, linked, above all, to eugenics. The philosopher demonstrates his concern with the way people understand each other in the environment in which they live, hence the interpretation that the right to personal identity is so important ${ }^{46}$.

By speaking of identity, Habermas states that when it comes to identity as a being of the species, several conceptions compete with each other. The naturalistic representations of man, verified in the language of physics, neurology, or evolutionary biology, concur with the classical conceptions of man exteriorized by religion and metaphysics. Yet, although they are at a higher level of generalization, reflections on the ethics of the species share with the ethical-existential reflections of the individual as well as with the ethical-political sphere of the nations with reference to a particular interpretation of life context. In the same way, in this case, cognitive research to know how human beings should understand themselves as exemplars of the human species, from the knowledge of relevant anthropological facts, joins the reflection that evaluates how each one intends to understand ${ }^{47}$.

It should be noted that self-understanding, repeatedly used in the Habermasian work, refers to the very construction of the identity of each individual, a process that is already impregnated with mishaps, such as the case of the imposition of an identity against one's wish, or which one is not ready to take ${ }^{48}$.

In fact, for Habermas, to perceive oneself worthy is something that goes through the construction of the personal identity of each subject, that is, the

45 J. Habermas, o futuro da natureza humana: a caminho de uma eugenia liberal?, trad. K. Jannini, Marins Fontes, São Paulo 2010, p. 32.

${ }^{46}$ Ibidem, p. 1.

47 Ibidem, pp. 1-2.

${ }^{48}$ Ibidem, pp. 46-47. 
:::: R. S. de Freitas, V. A. Mozetic, D. Zilio, Abortion...

way the individual sees himself, or analyzes himself from the inside to the outside, which is a primary condition to ensure his personal dignity is preserved, to the extent that his self-understanding becomes a parameter for that same dignity ${ }^{49}$.

Injured, then, the subject's right to self-understanding, consequently his personal dignity would indeed be hurt, because the way one perceives himself as a human being is part of his dignity, and his perception as an individual possessor of this same dignity.

Well, this point is made clear that, following the same reasoning, Jürgen Habermas also sought to reflect, in philosophical terms, the difficulty of conceptualizing the good life. Habermas defends the idea that post-metaphysical thought needs to be moderated when it comes to taking definitive positions on good or unsuccessful life ${ }^{50}$.

On this point, when Habermas questions whether there are post-metaphysical answers to the question about correct life, he reports that even today, practical philosophy does not totally renounce normative reflections ${ }^{51}$. However, in its entirety, it is limited to questions about justice, according to the author. It strives especially to elucidate the moral point of view that people adopt to judge norms and actions, whenever it constitutes what is of equal interest of each and equally good for all .

He argues that moral theory and ethics seem to be guided by questions concerning "what I should do" and "what we should do".

However, today's theories of justice and morality go their own way, different from that of ethics, taken in the classic sense of a correct doctrine of life.

In matters of greater relevance, Habermas reports, thus, that philosophy moves to a higher plane, analyzing only the formal properties of the processes of self-understanding, without, however, adopting a position on the content itself ${ }^{52}$.

In the same way, according to Charles Feldhaus, philosophy does not have the function of studying what constitutes the correct life for contem-

\footnotetext{
49 Ibidem, p. 50

50 Ibidem, p. 13.

51 Ibidem, p. 5.

52 Ibidem.
} 
porary pluralistic societies. It does not consist, as it has already been, in a set of practical advice about what would be a good and happy life ${ }^{53}$.

Based on this assumption, one can perceive the difficulty of taking positions, from the social point of view, on controversial subjects by nature, as is the case of abortion, since a consensus has not yet been built on what is or is not right.

Furthermore, Habermas mentions issues related to intrauterine human life and the controversy over what is right or wrong for one or all ${ }^{54}$. It makes clear that one in no way doubts the intrinsic value of life before birth, whether it is called "sacred", or deny such a sacralization of what constitutes an end in itself. However, the normative substance of the need to protect pre-personal life does not find a rationally acceptable expression for all citizens, neither in the objective language of empiricism nor in religion.

Thus, the concept of right or wrong in terms of strictly personal choices, or, as Habermas puts it, the concept of "good life" or "right life" seems far from peaceful ${ }^{55}$. The difficulty extends even further with regard to abortion and the possibility of a minimally peaceful solution, first with respect to moral issues, and then, and especially, in terms of legislation.

For this reason, and on the basis of valid discussion on the subject, it is controversial to take a position that is minimally peaceful about the problem from the social point of view. What is uncontroversial is the necessary protection of the rights inherent to women as the ultimate end to their own personal dignity.

\section{Conclusion}

The theme in which the study is based is controversial and has generated clashes and divergent opinions long ago. Issues related to abortion constan-

${ }^{53}$ C. Feldhaus, O Futuro da Natureza Humana de Jürgen Habermas: Um comentário, „Revista Internacional de Filosofia da Moral” 4 (2005), No. 3, p. 309.

${ }^{54}$ J. Habermas, op.cit., p. 46. It should be noted that Jürgen Habermas makes specific reference to liberal eugenics and a possible future construction of "perfect" human beings, hence his concern with intrauterine human life. However, it is possible to denote with exactitude its explication as it relates to the intrinsic value and to the "sacralization" of life still in formation (intrauterine).

${ }^{55}$ Ibidem, p. 1. 
:::: R. S. de Freitas, V. A. Mozetic, D. Zilio, Abortion...

tly spark heated discussions, and arguments that are favorable and contrary to practice are well-founded.

In the present research, a specific verification of the agenda was sought, that is, the assessment turned to the analysis of pro-abortion arguments, related mainly to decision-making autonomy (and the consequent right to self-determination of one's own body), right to privacy and the right to a woman's personal identity.

It should be reiterated that the present study does not have the bioethical analysis of the theories of the beginning of human life, nor does it question the mitigation or un-mitigation of the right to life in the hypothesis of a possible abortion, or even to delve into the dispute of right to life versus freedom of the pregnant woman. What was sought, however, was to permeate especially the area of argumentation concerning ideals favorable to abortion, so that one can reflect critically on the subject.

Thus, what was perceived was that ideals promoting abortion, based on rights such as decision-making autonomy, the right to self-determination, and the right to one's own body, are extremely plausible, and even if one does not agree with them, It may be overlooked that they are strong and that they protect a part of the population that is sometimes marginalized and historically considered to be more vulnerable (women), and that, therefore, deserves specialized protection. The material equality sought is in mind, although such vulnerability is questionable from the point of view of feminism itself.

And speaking of these ideals, it must be pointed out that the first of them, the decision autonomy, emphasizes each individual as the center of his own process, so that each person can make his choices, even without having to justify them, based on his Right to privacy, as was reiterated throughout the text. It is precisely this privacy that assures individuals the autonomy of decision.

The right to privacy also protects the identity to the degree that it distances decisions that go against the conceptions of each being, and in the case of pregnancy, it would be very invasive to impose the identity of a pregnant woman and a mother, to a woman who does not want it. This is according to the arguments put forward by advocates of abortion practice. Iden- 
tity came in the study also under the right to self-understanding, where the Habermasian thought was emphasized.

In this vein, the identity of the person is intrinsically linked to his body, from the moment that the body is one of the expressions of form of life of the individual. Thus, the importance of the right to one's own body for individuality and human identity is a recurrent reference to the right to one's own body by the defenders of the right to abortion.

In this way, maternity, from the point of view of nature, must be a decision, not a levy.

Therefore, what can be deduced is that, although there is some repulsion about abortion, due to religious, metaphysical, moral and ethical issues, as well as legal issues, one cannot turn a blind eye to the rights explained in this article, which serve as a basis for the defense of the right to abortion, because, to disregard such prerogatives would be to disregard the struggle waged by women for centuries, and their right to discern, and decide, based on their autonomous experience and what to do in the face of peculiar situations pertaining personal nature.

The study aims to investigate the right to privacy, decision-making autonomy and, profoundly, self-determination of the body as pro-abortion arguments. For that, an exploratory-explanatory, qualitative bibliographic research was carried out, using the deductive method. In relation to the results achieved, it is appreciated that, in fact, the arguments favorable to the practice deserve to be respected, since they are based on extremely important and solidly grounded rights. It follows, therefore, that there is extreme consistency in the justifications for abortion, and it must be taken into account, even though the arguments contrary to the practice deserve extreme respect. 